\title{
An unintended legacy: Kwame Nkrumah and the domestication of national self-determination in Africa
}

\author{
Andrew Small* \\ Legal Officer, Human Rights Advocacy Centre, Ghana
}

\begin{abstract}
Summary
In the early 1950s, the right to self-determination was a concept rich with disruptive potential for pre-independence Africa. Some saw the application of self-determination as an opportunity to redraw the continent's colonial borders; others believed it would lead to a pan-African union of states. Through an analysis of legal, historical and political material, this article argues that between 1958 and 1964 Ghana's first President, Kwame Nkrumah, although ideologically a pan-Africanist, played a pivotal but unintentional role in entrenching colonial era borders in Africa. The article identifies three key ways in which Nkrumah shaped the law of selfdetermination in Africa: first, by actively campaigning against 'tribalism' in Ghana; second, by enlisting the UN to prevent the secession of Katanga in 1960, thereby creating a crucial precedent; and, third, by playing a leading role in establishing the OAU in 1963, which went on to endorse the legal validity of colonial frontiers. In this way, Nkrumah helped settle arguments around the authentic self-determination unit in Africa, forging an unintended legacy that continues to shape the legal and political contours of the continent to the present.
\end{abstract}

Key words: self-determination; Banjul Charter; Ghana; Kwame Nkrumah; Organisation of African Unity; African Union; pan-Africanism; uti possidetis

BA LLB (University of Technology, Sydney) MSc (London School of Economics); A.N.Small@alumni.Ise.ac.uk 


\section{Introduction}

In the 1950s self-determination was a concept 'loaded with dynamite', 1 and this was no more the case than in pre-independence Africa. There were some who argued that self-determination should be seized as an opportunity to redraw the continent's colonial borders, while others believed that the application of the principle should lead to a pan-African union of states. All that was certain was the disruptive potential of self-determination. The article argues that during the crucial period between 1958 and 1964, Ghana's first President, Kwame Nkrumah, played a pivotal but unintentional role in settling these arguments. Although ideologically a pan-Africanist, Nkrumah helped entrench colonial era borders in Africa. The article identifies three key ways in which Nkrumah shaped the law of selfdetermination in Africa: first, by actively campaigning against 'tribalism' in Ghana; second, by enlisting the United Nations (UN) to prevent the secession of Katanga in 1960, thereby creating a crucial precedent; and, third, by playing a leading role in establishing the Organisation of African Unity (OAU) in 1963, which went on to endorse the legal validity of colonial frontiers. In this way, Nkrumah helped settle arguments around the authentic self-determination unit in Africa, forging an unintended legacy that continues to shape the legal and political contours of the continent to the present.

The article will draw out the unintended legacy of Nkrumah by briefly outlining the transatlantic education informing his beliefs on self-determination in the 1940s and 1950s, and how he applied or modified these beliefs during his time in power post-1952. The article then establishes Nkrumah's influence over the three key factors between 1958 and 1964 that shaped the law of self-determination in Africa, and demonstrates how these precedents continue to influence treaty and case law to the present. After considering some exceptions to the principle of uti possidetis juris ${ }^{2}$ and evolving standards, the article concludes by comparing Nkrumah's legacy with his intentions, and assessing whether the two might in the future be reconciled. In approaching the topic, the article makes use of Mayall's phrase 'the domestication of national self-determination', defined by Koskenniemi to denote the restriction of self-determination to the decolonisation project alone. ${ }^{3}$ This restriction is made possible through the principle of uti possidetis, which requires that the frontiers of a state follow the boundaries of its predecessor state.

1 D Philpott 'In defense of self-determination' (1995) 105 Ethics 352.

2 Uti possidetis juris (uti possidetis) is defined by Black's law dictionary as 'the doctrine that colonial administrative boundaries will become international boundaries when a political subdivision or colony achieves independence'. BA Garner et al Black's law dictionary (2007) 1582.

3 M Koskenniemi 'National self-determination today: Problems of legal theory and practice' (1994) 43 International and Comparative Law Quarterly 242. 


\section{Nkrumah's evolving views on self-determination}

\subsection{Origins of the concept of self-determination}

In its 1975 Western Sahara Advisory Opinion, the International Court of Justice (ICJ) described the essential component of selfdetermination as 'the freely-expressed will of the people'. ${ }^{4}$ Using this definition as a guide, the origins of the modern concept of selfdetermination arguably may be traced back to the late eighteenth century, when the Declaration of Independence of the United States of America (US) stated that governments derived 'their just powers from the consent of the governed'. In the decades following, the leaders of the French Revolution framed their own demands in terms of popular sovereignty. ${ }^{5}$

At the conclusion of World War I, self-determination re-emerged as a core principle of the Fourteen Points championed by US President Woodrow Wilson, which formed the basis of peace negotiations. While the ideal of self-determination remained mostly unrealised at this time, the concept subsequently was reflected in article 22 of the Covenant of the League of Nations, which devised the mandate system as a 'compromise solution' between self-determination and the interests of the major powers. ${ }^{6}$ At this time, self-determination remained a political rather than a legal concept. However, this changed during and following World War II. The 1941 Atlantic Charter and the 1945 UN Charter both affirmed peoples' rights to self-determination, laying the foundations - whether deliberately or not - for the independence and decolonisation movements that would unfold in the 1950s and 1960s.

\subsection{A pan-African conception of self-determination}

Readers will likely be familiar with the varied and tumultuous life of Ghana's first President, Kwame Nkrumah. However, for purposes of the article some key events are worth highlighting. Born in 1909 in the British colony in West Africa, then known as the Gold Coast, Nkrumah worked as a teacher in his home country until the age of 26. In 1935, he sailed for the United States, obtaining a Bachelor of Arts and a Bachelor of Theology degree from Lincoln University. He also earned two Master's degrees from the University of Pennsylvania in 1942 and 1943, in education and philosophy respectively. ${ }^{7}$ During his time in the United States, Nkrumah read Hegel, Karl Marx, Engels, Lenin and Mazzini and, in his own words, 'made time to acquaint myself with as many political organisations in the United States as I

Western Sahara (Advisory Opinion) (1975) ICJ Reports 81.

5 D Thürer \& T Burri 'Self-determination' (2008) Max Planck encyclopedia of public international law.

6 Thürer \& Burri (n 5 above).

7 RY Owusu Kwame Nkrumah's liberation thought: A paradigm for religious advocacy in contemporary Ghana (2005) 99. 
could ... the Republicans, the Democrats, the Communists and the Trotskyites'. ${ }^{8}$ During this frenetic period of academic and political education, Nkrumah developed the political philosophies that he would later bring with him to office in Ghana. In the early 1940s, he articulated a belief in the need for 'complete revolutionary change of the colonial system ${ }^{\prime 9}$ in Africa, to be replaced by a pan-African union unencumbered by colonial borders. ${ }^{10}$ In this sense, Nkrumah was arguing for self-determination in Africa in the form of state integration on a continental scale - with independence as a crucial first step.

\subsection{5 to 1952: From London to Accra}

Nkrumah followed his time in the United States with spells at the London School of Economics, University College London and Gray's Inn from 1945 to 1946. At this time, Africa consisted of over 40 countries, all but four of which - Ethiopia, Liberia, Egypt and South Africa - were controlled by a colonial power. However, with World War II concluded, change seemed increasingly inevitable. In October 1945, Nkrumah was a prominent delegate at the historic Pan-African Congress in Manchester, along with WEB DuBois, CLR James, Jomo Kenyatta, and 200 others. A declaration written by Nkrumah and endorsed by the Congress affirmed 'the right of all colonial peoples to control their destiny', 11 and another resolution similarly called for 'the implementation of the principles of the Four Freedoms and selfdetermination in the Atlantic Charter everywhere' ${ }^{12}$

Following this Congress, Nkrumah founded the West African National Secretariat (WANS), which had the realisation of 'United West African National Independence' as its primary objective. ${ }^{13}$ In February 1946, WANS held its first conference in London, with resolutions calling for 'the complete liquidation of the colonial system' and stating that 'existing territorial divisions in Africa [are] ... inimical to the best interests of the African peoples'. ${ }^{14}$ Given Nkrumah's central role in WANS, we can intuit that these resolutions reflect his own thinking on the topic at the time. Nkrumah's publications during the period provide further insight into how he thought the principle of self-determination should be applied in Africa. In September 1946, he wrote in the Nigerian newspaper The Comet that 'in all matters pertaining to the destiny of West Africa, personal and tribal differences, opinions and shortcomings must not be allowed to

8 K Nkrumah Ghana: The autobiography of Kwame Nkrumah (1957) 45.

9 A Biney The political and social thought of Kwame Nkrumah (2011) 24.

10 Biney (n 9 above) 15.

11 Biney 32.

12 The 5th Pan-African Congress 'Resolutions of the Pan-African Congress Manchester 1945' reproduced in C Legum Pan-Africanism: A short political guide (1965) 154.

13 Biney (n 9 above) 32.

14 M Sherwood 'Pan-African conferences, 1900-1953: What did "pan-Africanism" mean?' (2012) 4 The Journal of Pan-African Studies 111. 
hamper our struggle for ... unity $^{\prime}{ }^{15}$ In the 1947 pamphlet Towards colonial freedom, he went a step further, calling for a West African 'national entity'. ${ }^{16}$ At this stage, it appears that Nkrumah was grappling with whether to forge an African or West African union. However, what is not in doubt is his commitment to decolonisation and the reordering of colonial borders.

In late 1947 Nkrumah returned to the Gold Coast to take up the post of general secretary with the United Gold Coast Convention (UGCC), a recently-established political movement that aimed to end colonial rule. ${ }^{17}$ In this position, Nkrumah's efforts were focused on the realisation of self-determination within the Gold Coast, with his pan-African ambitions taking a back seat.

\section{Nkrumah and the concept of self-determination: 1951-1966}

\subsection{The period to 1960}

After a period of 14 months in prison - as punishment for promoting an illegal strike - Nkrumah was released in February 1951 and in March 1952 elected to the newly-created position of Prime Minister of the Gold Coast. During the subsequent period of shared government with the British colonial administration, known as the dyarchic partnership, Nkrumah published little and focused on the practical matter of governing. His biographer, Ama Biney, has argued that Nkrumah's ambitions for continental self-determination contracted during this period, and he was 'focused on the narrower aim of territorial independence before West African unity'. ${ }^{18}$ Upon leading the Gold Coast to independence in March 1957 and becoming Prime Minister of the renamed Ghana, Nkrumah once again broadened the scope of his ambition, stating that 'our independence will be meaningless unless it is linked up with the total liberation of Africa'. ${ }^{19}$

In 1958 Nkrumah convened the first Conference of Independent African States in Accra and was intimately involved in its preparations. ${ }^{20}$ Among the resolutions arising from that conference attended by representatives from Ghana, Libya, Ethiopia, Liberia, Morocco, Tunisia, Sudan and the United Arab Republic - were an affirmation of 'unswerving loyalty to and support of the Charter of the United Nations' and 'respect for the sovereignty and territorial

15 Sherwood (n 14 above) 111.

16 K Nkrumah Towards colonial freedom: Africa in the struggle against world imperialism (1962).

17 Biney (n 9 above) 35.

18 Biney 48.

19 BBC World Service 'Kwame Nkrumah's vision of Africa' BBC 14 September 2000 http://www.bbc.co.uk/worldservice/people/highlights/000914_nkrumah.shtml (accessed 24 January 2016). Biney (n 9 above) 136. 
integrity of all nations'. Another meeting in Accra in 1958 with which Nkrumah was closely involved, the All-African People's Conference, took a different tack. In a series of resolutions titled Frontiers, Boundaries and Federations, the Conference denounced 'artificial frontiers drawn by imperialist powers' and called for their abolition 'at an early date' ${ }^{21}$ As can be seen from these divergent resolutions, the form that self-determination would take in Africa was still very much undetermined in 1958.

In the following year, 1959, Nkrumah met with President Tubman of Liberia and President Sékou Touré of Guinea in the Liberian village of Sanniquellie to discuss African unity. Following the meeting, the three leaders released a Declaration of Principles affirming that 'each state and Federation, which is a member of the Community shall maintain its own national identity and constitutional structure' ${ }^{2} 2$ This compromise reflects a softening of Nkrumah's strident pan-African conception of self-determination in favour of an acknowledgment of the necessity of maintaining the territorial integrity of each individual state during the decolonisation project.

During this crucial time in the development of the law of selfdetermination in Africa, Nkrumah was also increasingly warning of the threat posed by 'balkanisation'. By this, he meant the splintering of states into groups based on pre-colonial tribal lines. Nkrumah argued that balkanisation of this kind would divide Africa into 'small, weak and unstable states', paving the way for neo-colonial interference. ${ }^{23}$ To this end, Nkrumah's government in 1957 declared a ban on tribal flags in Ghana and passed an Act prohibiting organisations from emphasising their 'racial or religious affiliations'. ${ }^{24}$ This forced emphasis on national rather than tribal identity was a reflection of Nkrumah's pragmatism, given that the colonial borders of Ghana cut through 17 major tribes. ${ }^{25}$

\subsection{0: Crisis in the Congo}

In 1960, Nkrumah - now President of Ghana - took his battle against balkanisation to the Republic of the Congo (now the Democratic Republic of the Congo (DRC)) during the attempted secession of Katanga. In his adopted role as pan-African statesman, Nkrumah acted as envoy between the UN, colonial powers and the Congolese leader Patrice Lumumba. Crucially, Nkrumah paid no credence to the claims of the Kantangese separatists, instead directing his efforts towards maintaining the borders that the Congo had inherited from

21 S Lalonde Determining boundaries in a conflicted world: The role of uti possidetis (2002) 115-116.

22 C Legum Pan-Africanism: A short political guide (1965) 45.

23 B Neuberger 'The African concept of balkanisation' (1976) 14 Journal of Modern African Studies 523.

24 Avoidance of Discrimination Act 38 of 1957 (Ghana).

25 W Zartman International relations in the new Africa (1966) 108. 
Belgium. In a speech to the Ghanaian National Assembly in August 1960, Nkrumah said that the 'greatest danger that Africa faces today is balkanisation' and that the crisis in the Congo represented a 'turning point in the history of Africa'. ${ }^{26}$ As Biney has noted, 'the principle of the indivisibility of Ghana and the Congo was sacrosanct and Nkrumah was prepared to defend it'. 27

Nkrumah emphasised these sentiments in an address to the UN in September 1960. 'The Congo, including Katanga and Kasai, is one and indivisible', he said. 'Any other approach is mere wishful thinking, for not all the mineral wealth in that integral part of the Congo can create Katanga as a separate state. ${ }^{28}$ Nkrumah was the first African leader to join Lumumba in appealing to the UN to help restore the Congo's territorial integrity. ${ }^{29}$ These efforts contributed to the adoption of UN Security Council Resolution 161 of 21 February 1961, which expressed grave concern at 'the prevalence of conditions which seriously imperil peace and order and the unity and territorial integrity of the Congo, and threaten international peace and security' ${ }^{30}$ This resolution, along with UN Security Council Resolution 143 from $1960,{ }^{31}$ authorised the use of force to preserve the Congo's territorial integrity. Ghana, under the direction of Nkrumah, was one of the first countries to contribute troops to the UN operation in the Congo in July 1960. ${ }^{32}$ These Ghanaian troops were joined by almost 20000 personnel from 30 countries during the period to July 1964. This episode, described variously as a 'game-changing precedent ${ }^{\prime 33}$ and an 'important landmark', ${ }^{34}$ demonstrated that the UN was prepared to sanction the use of force to quell a secession attempt in Africa. It is possible that the multi-national intervention would have occurred without Nkrumah's promotion. However, his eloquent advocacy for the Congo's territorial integrity played an essential part in rallying support from countries within and outside Africa. Furthermore, as Simpson has noted, this strong stance of the UN, 35

supported by Nkrumah and other African leaders, provided a basis for the Congo, Nigeria and other multi-ethnic countries threatened by secessionist

26 K Nkrumah 'Africa's challenge' speech delivered to the Ghanaian National Assembly, Accra, Ghana, 6 August 1960.

27 Biney (n 9 above) 160-161.

28 K Nkrumah et al 'Africa speaks to the United Nations: A symposium of aspirations and concerns voiced by representative leaders at the UN' (1962) 16 International Organization 316.

29 Biney (n 9 above) 160-161.

30 United Nations Security Council (UNSC) Resolution 161 (21 February 1961) UN Doc S/RES/161.

31 UNSC Resolution 14314 July 1960 UN Doc S/RES/143.

32 R Cavendish 'Upheaval in the Congo' (2010) 60 History Today.

33 J Genser \& B Ugarte 'Evolution of the Security Council's engagement on human rights' in J Genser \& B Ugarte (eds) The United Nations Security Council in the age of human rights (2014) 10.

34 M Shaw Title to territory in Africa: International legal issues (1986) 183.

35 B Simpson 'The Biafran secession and the limits of self-determination' (2014) 16 Journal of Genocide Research 339. 
movements to take whatever actions necessary to preserve their territorial integrity.

The Congo precedent quickly gained endorsement from regional and judicial bodies. In early 1961, a conference in Casablanca attended by Nkrumah - along with heads of state from Mali, Guinea, Morocco and representatives from Libya and the Algerian Republic - strongly supported the territorial integrity of the Congo. ${ }^{36}$ This was followed by the Lagos Conference of African States in 1962, at which attendees proclaimed the principle of respect for existing borders in Africa, and adopted a Charter affirming that 'each state has the right of defence of its territorial integrity' ${ }^{37}$ The actions of the UN in protecting the Congo's territorial integrity were also found to be legitimate by the IC] which, in an advisory opinion of July 1962, pronounced that expenses incurred during the operation were within the meaning of article $17(2)$ of the UN Charter. ${ }^{38}$

\subsection{Origins of the Organisation of African Unity}

With this precedent established, Nkrumah continued to take a leading role in organising newly-independent African states into a formal union. In 1963, he was instrumental in the creation of the Organisation of African Unity (OAU) at the Summit Conference of Independent African States in Addis Ababa. ${ }^{39}$ Nkrumah had intended, ahead of the Addis Ababa conference, that the formation of the OAU would mark the first step in a 'United States of Africa' controlled by a centralised government. ${ }^{40}$ This vision was shared by the so-called 'Casablanca group' of nations - of which Ghana was a member which favoured political integration as a prerequisite for economic integration and a socialist path to economic development. ${ }^{41}$ By contrast, the 'Monrovia group' favoured a gradualist approach to African unity that, instead of 'political integration of sovereign states', would entail 'unity of aspirations and of action'. ${ }^{42}$ At the conference, the arguments of the Monrovia group prevailed. Despite Nkrumah's advocacy, the OAU Charter in articles 2 and 3 explicitly stated that the

\footnotetext{
36 Legum (n 22 above) 192-199.

37 Shaw (n 34 above) 184.

38 Certain Expenses of the United Nations (article 17, paragraph 2 of the Charter) (Advisory Opinion) (1962) ICJ Reports 151 179-180.

39 O Onwumere 'Pan-Africanism: The impact of the Nkrumah years, 1945-1966' in T Falola \& N Afolabi (eds) Trans-Atlantic migration: The paradoxes of exile (2008) 237.

40 L Farmer 'Sovereignty and the African Union' (2012) 4 Journal of Pan-African Studies 96.

41 S Wapmu 'In search of greater unity: African states and the quest for an African Union government' (2009) 1 Journal of Alternative Perspectives in the Social Sciences 650.

42 B Franke 'Competing regionalisms in Africa and the continent's emerging security architecture' (2007) 9 African Studies Quarterly 34.
} 
purpose and principles of the OAU included protecting the sovereignty and territorial integrity of African states. ${ }^{43}$ Emerson concludes that ${ }^{44}$

the net effect of such pronouncements [in the Charter] as of the relevant sections of the 1960 UN Declaration is for all purposes to deny the legitimacy of any further disintegration or reshaping which impairs the integrity of the colonially defined states.

Notwithstanding his reservations, Nkrumah authorised the signature and ratification of the Charter by Ghana, and in September it entered into force after the requisite two-thirds of the 32 independent African states had also done so. ${ }^{45}$ Shaw has noted that the Charter did not 'specifically refer to the sanctity of the colonial borders', 46 although any ambiguity on this point was erased in 1964 when the OAU met in Cairo. Arising from this meeting was the Cairo Declaration, which declared that 'all member states pledge themselves to respect the borders existing on their achievement of national independence' ${ }^{47}$ Somalia and Morocco resisted the Resolution, but it was adopted by the OAU as a whole. While Nkrumah had said that the crisis in the Congo was 'the turning point in African history', the Cairo Resolution was of at least equal long-term significance in shaping the law of selfdetermination in Africa. In this regard, Shaw has written that 'the border resolution can be said to have marked the acceptance by Africa as a whole of a new territorial regime, one based on the legal validity of the colonial frontiers of independent states'. ${ }^{48}$ This marked a dramatic change from just six years earlier, when the All-African Peoples Conference had denounced the continent's 'artificial frontiers'. As arguably the most important individual behind the creation of the OAU, Nkrumah's influence helped pave the way for this increasing acceptance of colonial era borders, influencing the development of the law of self-determination in Africa thereafter.

\subsection{Placing Nkrumah's stance in context}

Before assessing Nkrumah's ongoing impact in shaping the law of selfdetermination as it would be applied in Africa, it is helpful to briefly consider the factors that informed his stance during the crucial period between 1958 and 1964. First and foremost, political pragmatism played a role; Nkrumah was an idealist, but also a canny and practicalminded politician. Thus, his homilies against tribalism and

43 Charter of the Organisation of African Unity (adopted 23 May 1963, entered into force 13 September 1963) 479 UNTS 39.

44 R Emerson 'Pan-Africanism' (1962) 16 International Organization 35.

45 C Legum 'The Organisation of African Unity: Success or failure?' (1975) 51 International Affairs 208.

46 Shaw (n 34 above) 185.

47 Organisation of African Unity 'Resolutions adopted by the first ordinary session of the Assembly of Heads of State and Government held in Cairo 17-21 July 1964' (1964) (Cairo Declaration). 
balkanisation were directed, in part, at people from the cocoaproducing Ashanti region who resisted Ghanaian federalism and formed their own separatist group, the National Liberation Movement. ${ }^{49}$ Notwithstanding this public stance against tribalism, Nkrumah was still prepared to use tribal loyalties as a lever to achieve political goals. In 1960, Ghana made an unsuccessful claim for the southeast corner of Côte d'Ivoire, on grounds of 'tribal unity' ${ }^{50}$ This claim formed part of an ongoing feud between Nkrumah and Côte d'Ivoire's independence leader, Félix Houphouët-Boigny. At around the same time, Nkrumah called for the integration of Togo into Ghana, also on the grounds of tribal unity.

Nkrumah's promotion of nationalism as a means of protecting state borders also had a pragmatic purpose. Even as President of Ghana he continued to believe in a pan-African union of African states with a centralised government and shared economic and military functions. ${ }^{51}$ It was no secret that Nkrumah saw himself as the likely leader of this federated United States of Africa, 52 although his public position was that he was 'prepared to serve ... under any African leader who is able to offer the proper guidance in this great issue of our time'. ${ }^{53}$ When, in 1963, the African heads of state chose to establish the OAU in such as way as to protect colonial borders, Nkrumah reluctantly signed the Charter. It is likely that he saw the maintenance of state stability as a necessary stepping stone towards genuine pan-Africanism. ${ }^{54}$ Nkrumah could not have anticipated, however, that through endorsing territorial integrity in this way, he was helping to lay the groundwork for the transformation of 'artificial' 55 colonial borders in Africa into a tangible and permanent reality.

\section{Nkrumah's unintended legacy: Uti possidetis in Africa}

\subsection{Pre-1958 potential of self-determination in Africa}

The writer and journalist Hardy recently wrote that 'many thought Africa's borders would change in the late 1950s and early 1960s, when most African nations broke free from colonial rule'.56 Indeed, before it was 'domesticated' in Africa in the 1960s, the disruptive potential of the principle of self-determination was immense. As

49 Biney (n 9 above) 45.

50 Shaw (n 34 above) 201.

51 K Nkrumah 'Proposal for a union government of Africa' speech at the OAU Summit Meeting, Cairo, Egypt, 19 July 1964.

52 Biney (n 9 above) 145.

53 K Nkrumah 'Speech to positive action conference for peace and security in Africa' Accra, Ghana, 7 April 1960.

54 African Union 'Kwame Nkrumah: The permanent relevance of a road-not-taken' 21 May 2013 http://summits.au.int/50th/50th/speeches/kwame-nkrumah-perma nenet-relevance-road-not-taken (accessed 24 January 2016).

55 K Nkrumah 'Letter to President Boigny' 14 January 1965 NAG: SC/BAA/430.

56 S Hardy 'A brief history of mapping' (2015) Chimurenga Chronic 2-3. 
Koskenniemi has argued, there is a revolutionary sense of national selfdetermination, linked to the principle's enlightenment origins, which 'far from supporting the formal structures of statehood provides a challenge to them'. ${ }^{57}$ When it was first formally articulated as a principle of international law at the time of World War I, selfdetermination was used as a vehicle for the re-division of Europe, rather than the maintenance of prior borders. ${ }^{58}$ In the 1921 Aaland Islands case, the Commission of Rapporteurs recognised this revolutionary potential of self-determination in a classic statement: ${ }^{59}$

To concede to minorities, either of language or religion, or to any fractions of a population the right of withdrawing from the community to which they belong, because it is their wish or their good pleasure, would be to destroy order and stability within states and to inaugurate anarchy in international life; it would be to uphold a theory incompatible with the very idea of the state as a territorial and political unity.

This potentially disruptive power of self-determination remained unresolved in the 1940s. During this decade, Aimé Césaire and Léopold Sédar Senghor argued that self-determination should be separate from state sovereignty, and decolonisation seized as an opportunity to remake the world. ${ }^{60}$ Some in the United States viewed self-determination not so much as an opportunity, but as a 'Pandora's box that might lead to state-fragmentation, genocide, or the proliferation of states too small or too primitive to merit selfgovernment'. ${ }^{61}$ And it was not just abroad that this potential was manifest: American Communists in 1939 were calling for the creation of an independent state in the South of the United States as an expression of 'black self-determination' ${ }^{62}$

In the African context, the revolutionary threat posed by selfdetermination was noted in the 1920 s by the Gold Coast nationalist Kobina Sekyi, who warned against Africa following the way of the Balkans. ${ }^{63}$ As noted above, the 'balkanisation' trope was revived in the 1950s by Kwame Nkrumah - among other African leaders - to argue against tribalism and small states. The fact that such arguments were deemed necessary demonstrates that the disruptive potential of selfdetermination was very much extant in Africa in the 1950s. As seen in the previous section of the article, however, events between 1958 and 1964 in which Nkrumah played a leading role helped defuse the revolutionary potential of self-determination in Africa by linking it to

\footnotetext{
57 Koskenniemi (n 3 above) 246.

58 J Anaya Indigenous peoples in international law (2004) 99.

59 Aaland Islands case (1920) League of Nations Official Journal Special Supplement 3.

60 G Wilder Freedom time: Negritude, decolonisation and the future of the world (2015).

61 B Simpson 'The United States and the curious history of self-determination' (2012) 36 Diplomatic History 676.

62 Simpson (n 61 above) 678.

63 JA Langley Pan-Africanism and nationalism in West Africa 1900-1945: A study in ideology and social classes (1973) 98.
} 
the principle of uti possidetis. The remainder of this section will demonstrate how treaty and case law embedded this trend into the law of self-determination in Africa from 1964 to the present.

\subsection{International law position on uti possidetis post-1964}

Nkrumah was forcibly deposed in 1966 in one of six military coups in Africa that year. However, the two key international events over which he had an influence - the UN intervention in the Congo and the formation of the OAU - continued to shape the law of selfdetermination in Africa. In 1966, the International Covenant on Civil and Political Rights (ICCPR) ${ }^{64}$ and the International Covenant on Economic, Social and Cultural Rights (ICESCR) ${ }^{65}$ were adopted by the UN General Assembly. In their shared first article, the ICCPR and the ICESCR state that 'all peoples have the right of self-determination' and state parties to the Covenants 'shall promote the realisation of the right of self-determination'. The UN Human Rights Committee subsequently clarified the implications of common article 1 in its General Comment 12 of $1984 .{ }^{66}$ As Shaw has noted, rather than sanctioning external self-determination, the Committee took the view that self-determination operated 'within the territorial framework of independent states [and] cannot be utilised as a legal tool for the dismantling of sovereign states'. ${ }^{67}$

In 1967 the membership of the OAU, building on their 1964 Cairo Resolution, adopted a resolution on the Biafran situation in Nigeria, declaring its 'condemnation of secession in any member states' 68 In this regard, it must be noted that despite the evolving norm of uti possidetis in Africa and the Katanga precedent, a minority of states (Côte d'Ivoire, Gabon, Tanzania and Zambia) did recognise and aid Biafra. In 1970, six years after the Cairo Declaration, the UN General Assembly Declaration on Principles of International Law reaffirmed states' territorial integrity, while also emphasising the importance of states conducting themselves in accordance with the selfdetermination of peoples. ${ }^{69}$

As Judge Yusuf of the IC) noted in 2013, ${ }^{70}$ the principle of territorial integrity enunciated in the Cairo Resolution is similar to Principle III on

64 International Covenant on Civil and Political Rights, UN General Assembly (19 December 1966).

65 International Covenant on Economic, Social and Cultural Rights, UN General Assembly (16 December 1966).

66 UN Human Rights Committee 'CCPR General Comment No 12: Article 1 (Right to self-determination), The right to self-determination of peoples' (13 March 1984).

67 M Shaw 'The heritage of states: The principle of uti possidetis juris today' (1996) 67 The British Year Book of International Law 123.

68 Organisation of African Unity 'Resolution on Situation in Nigeria' (1967) AHG/ Res.51 (IV).

69 Declaration on Principles of International Law concerning Friendly Relations and Co-operation among States in accordance with the Charter of the United Nations, UN General Assembly Resolution 2625 (XXV) 24 October 1970.

70 Frontier Dispute (Burkina Faso/Niger) (Judgment) ICJ Reports 2013. 
the inviolability of frontiers in the 1975 Helsinki Final Act of the Conference on Security and Co-operation in Europe. That Principle states that 'the participating states regard as inviolable all one another's frontiers as well as the frontiers of all states in Europe' ${ }^{71}$ The sentiments of the Cairo Resolution can also be found in the African Charter on Human and Peoples' Rights (African Charter), which entered into force in 1986. The African Charter affirms in article 20 the 'inalienable right to self-determination' of peoples, while also balancing this in article 29(5) with a duty incumbent upon the individual to 'preserve and strengthen the national independence and the territorial integrity of his country'. ${ }^{72}$ However, as will be seen in the discussion of the Katanga case below, these competing provisions of the African Charter were later interpreted conservatively to provide a presumption in favour of territorial integrity, except in the event of human rights abuses or a denial of the right to participate in government. ${ }^{73}$ This narrow interpretation of the right to selfdetermination in the African Charter is also evident in a report adopted by the African Commission on Human and Peoples' Rights (African Commission) in 2005, which states: ${ }^{74}$

The right to self-determination as entrenched within the provisions of the OAU Charter as well as the [African] Charter cannot be understood to sanction secessionist sentiment. Self-determination of peoples must therefore be exercised within the inviolable national boundaries of the state with due regard for the sovereignty of the nation-state.

Similar to the African Charter, the 1993 Vienna Declaration and Programme of Action balances the recognition of the 'inalienable' right to self-determination with 'the territorial integrity or political unity of sovereign and independent states' ${ }^{75}$ Finally, in 2001, when the OAU was reconstituted as the African Union (AU), its Constitutive Act in article 4(b) echoed the language of the 1964 Cairo Resolution, requiring 'respect of borders existing on achievement of independence'.

\subsection{Case law post-1964}

In addition to the treaty law outlined above, there is a wealth of case law endorsing the sanctity of colonial borders and the domestication of national self-determination in Africa. In this way, judicial bodies have cemented in international law the principle espoused in 1964 by

71 Organisation for Security and Co-operation in Europe 'Conference on security and co-operation in Europe (CSCE): Final Act of Helsinki' (1 August 1975).

72 African Charter on Human and Peoples' Rights (adopted 27 June 1981, entered into force 21 October 1986) 21 ILM 58.

73 Katangese Peoples' Congress v Zaire (Merits) (2000) AHRLR 72 (ACHPR 1995) (Katanga case).

74 Report of the African Commission's Working Group of Experts on Indigenous Populations/Communities (2005), adopted by the African Commission on Human and Peoples' Rights at its 28th ordinary session.

75 Vienna Declaration and Programme of Action, UN General Assembly (12 July 1993) A/CONF 157/23. 
Nkrumah's errant creation, the OAU. In its 1971 Namibia advisory opinion, the ICJ made its first reference to self-determination, interpreting it as the right of former colonies to independence. ${ }^{76}$ Four years later, in the Western Sahara opinion, the Court did not directly discuss or endorse uti possidetis, but did again emphasise that the right of self-determination was a basic principle of the decolonisation process. ${ }^{77}$ Just over a decade later, in 1986, the ICJ provided a crystalclear endorsement of uti possidetis in Africa in the Frontier Dispute (Burkina Faso/Mali) case. The Chamber began its analysis by emphasising in paragraph 20 the 'exceptional importance' of uti possidetis 'for the African continent and for the two parties' ${ }^{78}$ Later in the same paragraph, the Chamber stated that 'it [uti possidetis] is a general principle, which is logically connected with the phenomenon of the obtaining of independence, wherever it occurs'. In making this finding, the Chamber in paragraph 22 drew support from the 1964 Cairo Resolution on Border Disputes:

At their first summit conference after the creation of the OAU, the African heads of state, in their Resolution ... deliberately defined and stressed the principle of uti possidetis juris contained only in an implicit sense in the Charter of their organisation.

The resonance between this endorsement of the colonial borders in the Burkina Faso/Mali judgment and the 1964 Cairo Declaration has been noted by Maogoto, who wrote of the ruling: 'A political statement in 1964, some two decades later, had meshed with a judicial pronouncement. $^{.79}$ This pronouncement led the Chamber to decide that the two states in the matter - Burkina Faso and Mali - had an obligation to respect pre-existing international frontiers. Following this decision, the principle of uti possidetis has also been found to apply to maritime boundaries in Africa. In an Arbitral Award case of 1989 between Guinea-Bissau and Senegal, the Tribunal decided that 'from a legal point of view, there is no reason to establish different regimes dependent of which material element [land or sea] is being delimited'. ${ }^{80}$ This finding represents a significant contribution to developing state practice on maritime delimitation in Africa.

The 1992 Katanga case is also of significant normative value, as it was the first decision of the African Commission to address the possible right to external self-determination in post-independence Africa. In the case, the African Commission was called on to decide whether people in the region of Katanga in Zaire (as it was then

$76 \mathrm{~K}$ Roepstorff The politics of self-determination: Beyond the decolonisation process (2012) 18.

77 Western Sahara (Advisory Opinion) (1975) ICJ Reports.

78 Frontier Dispute (Burkina Faso/Mali) (Judgment) (1986) ICJ Reports.

79 J Maogoto 'Somaliland: Scrambled by international law?' in D French (ed) Statehood and self-determination: Reconciling tradition and modernity in international law (2013) 216.

80 SN Lalonde \& MG Kohen 'Determining boundaries in a conflicted world: The role of "uti possidetis"' (2004) 98 American Journal of International Law 133. 
known) could exercise their right to self-determination in the form of secession or independence. The claim was brought under article 20(1) of the African Charter. Mhango has stated that in its decision, the African Commission 'relied on the Cairo Resolution in setting the standard by which the right to self-determination would be implemented in post-independence Africa' ${ }^{81}$ As noted above, the Commission found that invoking the principle of self-determination was not enough. In the absence of 'concrete evidence of violations of human rights', it was obliged 'to uphold the sovereignty and territorial integrity of Zaire'. ${ }^{82}$ Mhango asserts that this decision, coupled with the ICJ ruling in the Frontier Dispute (Burkina Faso/Mali) case, means that 'claims of self-determination in the form of secession are [now] prohibited under the African Charter in favour of claims that can be achieved without altering existing state boundaries'. Regardless of whether this is categorically true, there is no doubt that the decision in the Katanga case assisted in carrying forward the principle of uti possidetis that had been articulated in the 1964 Cairo Resolution.

Case law cementing the principle of uti possidetis in Africa has continued from the Katanga case to the present. In deciding a border dispute between Libya and Chad in 1994, the ICJ endorsed a colonial era treaty between Libya and France from 1955, even though the treaty was no longer in force. ${ }^{83}$ A 1996 decision by a delegation of the African Commission - sent to Senegal with the aim of resolving the Casamance separatist movement - considered grounds for independence including 'historical legitimacy', but ultimately rejected the claim in favour of preserving Senegal's territorial integrity. ${ }^{84}$ Another significant decision is the Kasikili/Sedudu Island case of 1999, involving Botswana and Namibia. ${ }^{85}$ In this matter, the court held that while Namibia had historically occupied the island, a treaty between two colonial powers (Germany and England) from 1890 was of greater value in establishing the boundary between the two nations. This decision demonstrates the prominence accorded to uti possidetis in Africa, as the Chamber valued the principle above evidence of actual human occupation.

The 2002 Case Concerning the Land and Maritime Boundary between Cameroon and Nigeria also provides evidence of the ongoing influence of the OAU's 1964 Cairo Resolution. The ICJ Chamber in this matter

81 M Mhango 'Governance, peace and human rights violations in Africa' (2012) 5 African Journal of Legal Studies 199.

82 Katanga case (n 73 above).

83 Territorial Dispute (Libyan Arah Jamuhiriya/Chad) (Judgment) (1994) ICJ Reports.

84 African Commission on Human and Peoples' Rights 'Report on the Mission of Good Offices to Senegal of the African Commission on Human and Peoples' Rights: 1-7 June 1996' (1996).

85 Kasikili/Sedudu Island (Botswana/Namibia) (Judgment) (1999) IC) Reports. 
invoked the Cairo Resolution in paragraph 77 of their decision, and went on to state: ${ }^{86}$

This principle clearly means that Nigeria could not challenge today a boundary which existed for 47 years before its independence and which Nigeria itself unequivocally accepted as the boundary between its territory and that of Cameroon from 1960 to 1977.

The 2005 Frontier Dispute (Benin/Niger) case concerned a situation in which both parties agreed to be bound by uti possidetis, even though at the time of independence the 'territorial boundaries were no more than delimitations between different administrative divisions or colonies subject to the same colonial authority' ${ }^{87}$ In its decision, the Chamber emphasised that the principle of uti possidetis had on multiple occasions been recognised in the African context, and that 'it was recognised again recently, in article 4(b) of the Constitutive Act of the African Union' ${ }^{88}$ A subsequent decision of the $[\mathrm{CJ}$, the Frontier Dispute (Burkina Faso/Niger) ruling of 2013,89 settled a boundary dispute between the two nations with reference to a map published by a French government agency in 1960. In paragraph 63 of the judgment, the Chamber noted that 'amongst the rules of international law applicable to the dispute' is 'the principle of the intangibility of boundaries inherited from colonisation'. The Chamber also endorsed a 2009 Special Agreement between Niger and Burkina Faso, which used similar wording to the 1964 Cairo Resolution. ${ }^{90}$ In this way, the Court indicated that the principle of uti possidetis was just as applicable in contemporary Africa as it was in 1964, when the assembled African leaders in Cairo adopted their historic resolution. In other words, Nkrumah's unintended legacy continues to unfold.

\section{Exceptions and evolving standards}

\subsection{Outlying cases}

The narrative of the section above suggests an iron-clad endorsement of uti possidetis in Africa within international treaty and case law. The actual story, however, is slightly more nuanced, and punctuated with exceptions to the principle. One of the first exceptions occurred even before the 1964 Cairo Resolution was adopted, in the case of Somaliland. A former British protectorate, Somaliland attained independence on 26 June $1960^{91}$ only to unite five days later with the Trust Territory of Somalia. ${ }^{92}$ The union was enacted with no popular

86 Case Concerning the Land and Maritime Boundary between Cameroon and Nigeria (Cameroon v Nigeria: Equatorial Guinea Intervening) (Judgment) (2002) ICJ Reports.

87 Frontier Dispute (Benin/Niger) (Judgment) (2005) ICJ Reports.

88 As above.

89 Frontier Dispute (Burkina Faso/Niger) (Judgment) (2013) ICJ Reports.

90 Frontier Dispute (Burkina Faso/Niger) (n 89 above) 63.

91 R Rahn 'Curious case of Somaliland' Washington Times 6 January 2005.

92 Maogoto (n 79 above) 210. 
vote and no attempt to gauge the opinion of the population of either part of the country. Yet, despite subsequent movements towards statehood, Somaliland to this day remains 'tied ... through the independence union [of 1960]'. ${ }^{93}$ Poore has argued that the case of Somaliland represents an exception to uti possidetis because 'the new borders [of the Republic of Somalia] clash with those delineated by Great Britain, France, Ethiopia, and Italy during the colonial period'. ${ }^{94}$ Maogoto stated that the borders of the Republic of Somalia 'breach' the 1964 Cairo Resolution, and blames this on 'the two Somalias' ... rush to union'.95

The case of Eritrea and Ethiopia also represents an instance where borders were drawn up and sanctioned in the years after World War II in conflict with the principle of uti possidetis. During the colonial period, Ethiopia and Eritrea had remained separate states: From 1890 to 1935, Ethiopia was an independent member of the international community, while Eritrea was a colony of Italy. ${ }^{96}$ This arrangement was enshrined in three boundary agreements concluded between Italy and Ethiopia in 1900, 1902, and 1908. Nonetheless, UN General Assembly Resolution 390(V) of 1950 recommended that Eritrea and Ethiopia be joined in a federation 'under the sovereignty of the Ethiopian Crown'.97 After the two countries were formally joined in 1952, Ethiopia declared the boundary agreements and the Eritrean Constitution null and void, and incorporated Eritrea into Ethiopia as a province. ${ }^{98}$ This laid the groundwork for a decades-long independence movement within Eritrea, which culminated with Ethiopia recognising Eritrea's sovereignty in 1993. Fighting continued, however, and in 2000 a new peace treaty was signed in Algiers, mediated by Rwanda and the United States. Per article 4(1) of the Algiers Peace Agreement, the boundary dispute between Eritrea and Ethiopia was settled with regard to colonial agreements from the early twentieth century. ${ }^{99}$ Thus, the principle of uti possidetis was belatedly applied to the territories, with the effect that the boundary of 1935 between Eritrea and Ethiopia remains the boundary of today.

Another exception to the application of uti possidetis in Africa can also be found in the successful secession of South Sudan from Sudan in 2011. When Sudan gained independence in 1956, respect for colonial frontiers required that South Sudan remain a part of the

93 Maogoto 212.

94 B Poore 'Somaliland: Shackled to a failed state' (2009) 45 Stanford Journal of International Law 142.

95 Maogoto (n 79 above).

96 Decision regarding delimitation of the border between Eritrea and Ethiopia, Reports of International Arbitral Awards, United Nations Vol XXV (13 April 2002) 83-195.

97 Report of the United Nations Commission for Eritrea, UN General Assembly Resolution 390(V) 2 December 1950.

98 Decision regarding delimitation of the border between Eritrea and Ethiopia, Reports of International Arbitral Awards, United Nations Vol XXV (13 April 2002) 83-195.

99 Peace Agreement between Ethiopia and Eritrea signed on 12 December 2000 in Algiers. 
country, as the two parts had been 'officially united' by Britain at the 1947 Juba Conference. ${ }^{100}$ This adherence to a border created for the 'administrative convenience of British colonialists' joined people separated 'by two of the continent's biggest religious and linguistic divides'.101 Following two wars for independence fought by South Sudan over 60 years, South Sudan was permitted a referendum for independence outside of colonial borders. This was against the initial wishes of the $A U$, which believed that independence for the south would lead to further conflict. ${ }^{102}$ Following the vote, South Sudan became an independent nation in July 2011. One consequence of the division is that the Abyei area remains in Sudan, even though its residents are primarily Dinka - the largest ethnic group in South Sudan. In October 2013, residents of the Abyei region held a unilateral referendum in which 99 per cent of voters chose to join South Sudan. The vote was condemned by the AU as 'unacceptable and irresponsible', indicating that the AU was keen to ensure the division of Sudan against the principle of uti possidetis remains an outlying case, rather than setting a precedent that other contested regions ${ }^{103}$ may be tempted to replicate. ${ }^{104}$

\subsection{Evolving standards}

While the principle of uti possidetis was enforced with rigour during the decolonisation process, there are signs that a reassessment of the form it should take is underway - in Africa, and elsewhere. This is evident in the 1995 Constitution of Ethiopia, which in article 39(1) provides its ethnic units with the 'unconditional right to selfdetermination, including the right to secession'. ${ }^{105}$ The 1996 Constitution of South Africa also provides for self-determination, recognising in section 235 the 'right of self-determination of any community sharing a common cultural and language heritage'. ${ }^{106}$

At a regional level, article 20 of the African Charter, which entered into force in 1986, has been interpreted to entail the 'possible application of the principle of the right of peoples to selfdetermination in a post-decolonisation context' 107 The article leaves open the possibility of external self-determination, an open conflict with the principle of uti possidetis. Article 20(2) of the African Charter

100 M Sterio The right to self-determination under international law (2013) 165.

101 Sterio (n 100 above) 166.

102 J Gettleman 'In Sudan, a colonial curse comes up for a vote' New York Times 8 January 2011.

103 Eg Western Sahara, Somaliland, the Ogaden region in Ethiopia or the Cabinda enclave in Angola.

104 A Lucey 'The referendum in Abyei is an ongoing challenge for the African Union' (2013) Institute for Security Studies.

105 Constitution of the Federal Democratic Republic of Ethiopia, 21 August 1995.

106 The Constitution of the Republic of South Africa, 1996.

107 F Ouguergouz The African Charter on Human and Peoples' Rights: A comprehensive agenda for human dignity and sustainable democracy in Africa (2003) 268. 
also arguably permits 'the right to rebellion'108 in cases of extreme oppression. In this sense, the Charter could be said to make provision for the violent form of self-determination Fanon spoke of during his 1958 address to the All-African People's Conference in Accra. ${ }^{109}$ While the African Charter, therefore, provides a relatively wide scope for recognising self-determination claims, the Constitutive Act of the $A U$ is less permissive. It contains no direct reference to self-determination, although it does state in article $3(\mathrm{~h})$ that one of the objectives of the $\mathrm{AU}$ is to promote and protect human rights in accordance with the African Charter. As the case of South Sudan demonstrates, however, the $A U$ is firmly in favour of maintaining territorial integrity, except in the most extreme cases and where external pressure is applied. In this way, it can be seen that the $A U$ is endeavouring to limit any potential evolution in the concept of self-determination in Africa through a conservative interpretation of the African Charter and its own Constitutive Act.

Internationally, the trend towards a post-uti possidetis interpretation of the principle of self-determination is also evident. In 1991, the United Nations Educational, Scientific and Cultural Organisation (UNESCO) declared that self-determination 'is not confined to a right to be enjoyed by formerly colonised peoples. It is not a right to be enjoyed once only and thereafter to be forever lost. ${ }^{110}$ Similarly, the Supreme Court of Canada in 1998 recognised the right of selfdetermination as a general principle of international law, which may in certain circumstances be extended to secession outside the colonial context, overruling the principle of territorial integrity. ${ }^{111}$ The Independent International Commission on Kosovo has also affirmed this point, stating in the Kosovo Report of 2000 that the moral and political duty of the international community 'arguably ... extends to the realisation of the right of self-determination for the people of Kosovo'. 112

Commentators have seized on these developments as evidence of a 'new definition' of self-determination. In 2006, Hannum wrote: 113

Following several years of indecision, the international community has moved towards a new definition of self-determination ... [that] continues to exclude the possibility of unilateral, non-consensual secession, but has become infused with broadly defined human, minority and indigenous rights.

108 Ouguergouz (n 107 above) 267.

109 Republished in F Fanon The wretched of the earth (1965).

110 UNESCO 'Statement to the UN Sub-Commission on the Prevention of Discrimination and Protection of Minorities' (1991) UN Doc E/CN.4/Sub.2/1992/6 para 3(d).

111 Reference re Secession of Quebec (1998) 2 SCR 217.

112 Independent International Commission on Kosovo The Kosovo Report: Conflict, international response, lessons learned (2000) 186.

$113 \mathrm{H}$ Hannum 'Self-determination in the 21st century' in E Babbit \& H Hannum (eds) Negotiating self-determination (2006) 61. 
Anaya has signalled the end times for uti possidetis, noting that 'under contemporary international law ... the doctrine of sovereignty and its Charter affirmations are conditioned by ... human rights values'. $^{114}$ Taking a different tack, Koskenniemi has written of the 'post-modern challenge' to African states' territorial integrity in the form of tribalism and 'the establishment of self-defence communities'. 115 Flourishing informal economies, which in some African countries account for up to 65 per cent of gross domestic product (GDP), ${ }^{116}$ are also said to be an example of this ceding of state power to regional and local communities. Such developments are significant as they represent a modern sanctioning of the 'balkanisation' and tribalism that Nkrumah warned of during his time. This is not necessarily a negative result: As the cases of Eritrea and Sudan have taught us, the ideological maintenance of a border delineated at independence can pose a far greater threat than secession. Furthermore, as Singapore ${ }^{117}$ (and perhaps Monaco) demonstrate, a state's small size need not act as a barrier to its success.

\section{Conclusion}

Freed from the constraints of power in 1966, Nkrumah revived and redoubled his strident pan-African beliefs while living in exile in Conakry. 'Yes, indeed, the African revolution should recognise none of the colonial frontiers between African territories or states', he wrote in 1967. 'They are indeed artificial boundaries. ${ }^{118}$ Despite his protestations, however, Africa was veering down a different course. Since 1964 the sanctity of the continent's colonial borders has been endorsed by treaty and case law, with only a handful of outlying exceptions. At a time when almost 80 per cent of Africa is still off limits to travellers from within the continent who do not hold a visa, the pan-African ideal seems as distant as ever. ${ }^{119}$ Rather than African unity, the opposite trend - towards tribalism, decentralisation and secession - has emerged on the continent, as the evolving standards outlined above illustrate. Were he alive today, Nkrumah would likely decry this development as harmful 'balkanisation'. However, it is this 'post-modern' path upon which self-determination seems set to continue.

114 Anaya (n 58 above).

115 Koskenniemi (n 3 above).

116 International Monetary Fund 'Sub-Saharan Africa regional economic outlook: Restarting the growth engine' May $2017 \mathrm{x}$.

117 J Irving 'Self-determination and colonial enclaves: The success of Singapore and the failure of theory' (2008) 12 Singapore Yearbook of International Law 97.

118 Biney (n 9 above) 169.

119 African Development Bank Group 'Africa Visa Openness Report 2017' (2017) 12. 
As the article has shown, the principle of uti possidetis played a dominant role in the application of self-determination in Africa during the independence era, and its limitation thereafter. Nkrumah's unintended propagation of this principle, which laid the foundations for the domestication of national self-determination in Africa, was threefold. First, he sought to limit tribalism in Ghana in favour of nationalism; second, he led the intervention in the Congo in 1960 to prevent external self-determination by the Katangese people; and, third, he was instrumental in the establishment of the OAU, which in 1964 made an unequivocal statement in favour of uti possidetis that became a cornerstone of African regional law and politics. ${ }^{120}$ In this way, Nkrumah helped settle arguments around the authentic selfdetermination unit in Africa, and forged an unintended legacy that continues to shape the legal and political contours of the continent to the present.

120 S Dersso 'International law and the self-determination of South Sudan' (2012) Institute for Security Studies. 